\title{
Prestisje og prioritering
}

Hjertet og hjernen er i vår kultur symboltunge organer - de definerer livet og døden og er bærere av selvet. Da er det kanskje ikke så rart at når leger i en undersøkelse fra 1991 rangerte 38 sykdommers prestisje, havnet hjerteinfarkt og hjernesvulst på henholdsvis første- og tredjeplass (1). Hvordan kan det ha seg at hjerneslag kun oppnådde en begredelig 33. plass? Forklaringen er at sykdommers prestisje ikke bare handler om organet de sitter i. Også en lang rekke andre kjennetegn ved sykdommen, som prognose og behandlingsmuligheter, bestemmer plasseringen i hierarkiet.

Spiller det noen rolle for pasientene hvordan leger bedømmer sykdommers prestisje? Det ser slik ut, fordi sykdommer som rangeres høyt, også prioriteres høyt. Sykdommer det forskes på slik at behandling og prognose bedres, stiger i prestisjehierarkiet - og prioriteres dermed ytterligere. Situasjonen for hjerneslag i 1991 liknet mye på situasjonen for hjerteinfarkt 30 år tidligere: Prognosen var dårlig, behandlingsmulighetene få, og det fantes ikke dedikerte sykehusenheter for sykdommen. En av de aller forste studiene som dokumenterte effekt av dedikerte hjerteovervåkingsenheter i sykehus, ble i 1963 refusert av British Medical Journal. Begrunnelsen var at det ville være «uansvarlig å foreslå at alle pasienter med hjerteinfarkt skulle bli innlagt $i$ avdelinger hvor de kunne motta intensivbehandling» (2). Først langsomt vant tanken om egne enheter for hjerteinfarktpasienter frem. Denne fundamentale strukturelle endringen ble grunnlaget for økt oppmerksomhet samt utvikling av forebyggende strategier og effektiv behandling. Ga dette grunnlag for økt prestisje for sykdommen? Det vet vi ikke, men insidens og dødelighet av hjerteinfarkt falt betydelig de påfølgende tiårene.

Historien om håndtering av akutt cerebrovaskulær sykdom er på mange måter en forsinket parallell til dette. I 1975 ble den første moderne slagenheten i sykehus innviet (3). Enhetene tok opp i seg elementer både fra hjerteovervåking og rehabiliteringsmedisin og har i utallige studier vist seg å være effektive for å minske både sykelighet og dødelighet etter hjerneslag. I kjølvannet av økt oppmerksomhet har cerebrovaskulær forskning stadig utviklet ny kunnskap. Mange viktige risikofaktorer er avdekket. Trombolytisk behandling er i dag hjørnesteinen i den medikamentelle akuttbehandlingen. Nevroradiologisk utvikling har revolusjonert den diagnostiske presisjonen, og det er utviklet flere ulike typer endovaskulær behandling. Den medisinske utviklingen har gjort hjerneslag til en hastediagnose. Hva vil dette bety for pasientpopulasjon og diagnosespekter i fremtidens slagenheter? To artikler i dette nummer av Tidsskriftet lar oss ane konturene av det $(4,5)$. Begge omhandler pasienter innlagt ved slagenheten ved Haukeland universitetssykehus. Thomassen og medarbeidere (4) fant at nær halvparten av pasientene hadde andre diagnoser enn hjerneslag. Av den halvdelen som hadde sikker cerebrovaskulær sykdom, hadde $10 \%$ transitorisk iskemisk attakk (TIA), og $72 \%$ hadde ingen eller lette nevrologiske utfall. Rundt halvparten av pasientene med hjerneinfarkt i denne studien hadde en liggetid på under sju døgn. Helsedirektoratets retningslinje fra 2010 tilsier at pasienter med sannsynlig gjennomgått cerebrovaskulær sykdom uten symptomer på henvendelsestidspunktet eller åpenbare risikofaktorer ved prehospital vurdering ikke engang skal vurderes i sykehus, og at en liggetid på under sju døgn for de øvrige ikke er å anbefale (6). Næss og medarbeidere beskriver et treårsmateriale av pasienter med akutt hjerneinfarkt innlagt i den samme slagenheten (5). Trombolyse- graden var på imponerende $15 \%$, og alle pasienter gjennomgikk et omfattende utredningsprogram. Hos $20 \%$ av pasientene uten kjent atrieflimmer på forhånd avslørte 24-timers EKG flimmer. Akuttutredningen er viktig for raskt å avdekke kjente risikofaktorer. Allikevel forble etiologien ukjent hos nærmere $40 \%$ av pasientene. Moderne hjerneslagutredning rår over et omfattende arsenal av supplerende undersøkelser. Senere studier må avklare hvor grensen går mellom maksimal utredning og maksimal klinisk nytte.

På samme måte som enhetene for hjerteinfarkt etter hvert endret karakter - fra overvåking og mobilisering til aktiv medikamentell og endovaskulær intervensjon - er nå også de akutte slagenhetene i forandring. Tradisjonelt har deres viktigste akuttoppgaver vært overvåking, tidlig mobilisering, komplikasjonsforebygging og kompetent sykepleie (7). Funnene i de to studiene fra Bergen kan tyde på at rask diagnostisk og terapeutisk avklaring vil bli det viktigste for majoriteten av pasientene. Ny innsikt og nye muligheter er i ferd med å endre synet på slagenhetenes organisering og oppgaver. Dette peker frem mot en ny type enhet preget av lavere terskel for innleggelse, kortere liggetider og hyppigere bruk av avansert bildediagnostikk. Flere av anbefalingene i Helsedirektoratets retningslinje fra 2010 (6) kan allerede være i utakt med utviklingen.

I 2002 utførte Album \& Westin en ny undersøkelse av 38 sykdommers prestisjehierarki (8). Hos erfarne leger lå hjerneslag på 29. plass, knapt endret fra 1991. Hos medisinstudentene, derimot, oppnådde hjerneslag 22. plass. Vi kan ikke vite hvorvidt dette skyldes dedikerte slagenheter, mer oppmerksomhet og økte behandlingsmuligheter. Det vi vet, er at hjerneslag fortsatt er en av de viktigste årsakene til invaliditet og den tredje vanligste dødsårsaken (6). Vi har oppnådd mer kunnskap om denne sykdommen de siste fire tiårene enn de fire foregående tusenårene (3). Det gir håp om at sykdommens prestisje blant leger vil øke og at akutt hjerneslag vil bli prioritert høyere både pre- og intrahospitalt. For pasientene kan det bidra til at sykelighet og dødelighet av hjerneslag kan fortsette å falle, slik som for hjerteinfarkt.

\section{Are Brean}

are.brean@legeforeningen.no

Are Brean (f. 1965) er medisinsk redaktør i Tidsskrift for Den norske legeforening, overlege ved Nevrologisk avdeling, Oslo universitetssykehus, og leder i Norsk nevrologisk forening. Ingen oppgitte interessekonflikter.

\section{Litteratur}

1. Album D. Sykdommers og medisinske spesialiteters prestisje. Tidsskr Nor Lægeforen 1991; 111: 2127-33

2. Julian DG. The evolution of the coronary care unit. Cardiovasc Res 2001; 51: $621-4$.

3. Hachinski V, Donnan GA, Grelick PB et al. Stroke: working toward a prioritized world agenda. Stroke 2010; 41: 1084-99

4. Thomassen L, Waje-Andreassen U, Næss H et al. Behandling av cerebrovaskulære sykdommer i slagenhet. Tidsskr Nor Legeforen 2011; 131: 819-23.

5. Næss H, Waje-Andreassen U, Brøgger J et al. Pasienter med akutt hjerneinfarkt innlagt i slagenhet. Tidsskr Nor Legeforen 2011; 131: 814-8.

6. Nasjonal retningslinje for behandling og rehabilitering ved hjerneslag. Oslo: Helsedirektoratet, 2010. www. helsedir.no/publikasjoner [1.4.2010)

7. Indredavik B. En effektiv slagenhet - hva er det? Tidsskr Nor Lægeforen 2007; 127: $1214-8$

8. Album D. Westin S. Do diseases have a prestige hierarchy? A survey among physicians and medical students. Soc Sci Med 2008; 66: 182-8. 